\title{
Electrolytic Balance in Broiler Chicks During the First Week of Age
}

Balanço Eletrolítico Para Frangos de Corte na Primeira Semana de Idade

Autor(es) / Author(s)

Borges $\mathrm{SA}^{1}$

Maiorka $A^{1}$

Laurentiz $\mathrm{AC}^{1}$

Fischer da Silva $\mathrm{AV}^{2}$

Santin $E^{1}$

Ariki J ${ }^{1}$

1-FCAV / Unesp, Jaboticabal

2- Depto. de Fisiologia - Universidade Federal do Paraná, Curitiba

\section{Correspondência / Mail Address}

Ana Vitória Fischer da Silva

Depto. de Fisiologia - UFPR / SCB

Caixa Postal 19031

Centro Politécnico - Jd. das Américas

81531-990 - Curitiba - PR - Brasil

E-mail: avitoria@bio.ufpr.br

Unitermos / Keywords

cloro, eletrólitos, frangos, potássio, sódio

broilers, chlorine, electrolytes, potassium, sodium

\section{ABSTRACT}

Two experiments were carried out using 712 day-old chicks to evaluate the electrolytic balance ( $\mathrm{Na}+\mathrm{K}-\mathrm{Cl})$ in pre-starter (1-7 days) broiler diets. The feed, based on corn and soybean meal with $21.5 \%$ protein and 2,900 kcal ME/kg, was offered ad libitum. In experiment I, $\mathrm{K}$ level was fixed, and $\mathrm{Na}$ and $\mathrm{Cl}$ levels were changed, using four treatments and eight replicates of 16 birds. In experiment II, increasing levels of $\mathrm{Na}$ and $\mathrm{K}$ were used, with a total of four treatments and five repetitions of 10 birds. In both experiments, the dietary electrolytic balance was 40; $140 ; 240$ and $340 \mathrm{mEq} / \mathrm{kg}$. Electrolytic balance caused a quadratic effect on weight gain and feed:gain ratio, and a linear increase in feed intake when the electrolytic balance was increased by the single supplementation of $\mathrm{Na}$, indicating that this ion stimulates feed intake of birds at this stage. However, feed intake was maximum for $202 \mathrm{mEq} /$ $\mathrm{kg}$, when $\mathrm{K}$ and $\mathrm{Na}$ levels were concurrently increased in the diet, indicating that there is a limit over which feed intake is depressed as a function of excessive $\mathrm{K}$. The ideal electrolytic dietary balance was between 246 and $277 \mathrm{mEq} / \mathrm{kg}$, obtained by the manipulation of $\mathrm{Na}$ and $\mathrm{Cl}$ levels.

\section{RESUMO}

Foram conduzidos dois experimentos, utilizando-se 712 pintos de corte para avaliar o efeito do balanço eletrolítico $(\mathrm{Na}+\mathrm{K}-\mathrm{Cl})$ em rações préiniciais (1-7 dias) de frangos de corte. As rações à base de milho e farelo de soja, com 21,5\% de proteína e $2.900 \mathrm{kcal} \mathrm{EM} / \mathrm{kg}$, foram oferecidas à vontade. No experimento I, o nível de $\mathrm{K}$ foi fixado e os níveis de $\mathrm{Na}$ e $\mathrm{Cl}$ foram manipulados, em 4 tratamentos com 8 repetições de 16 aves cada. No experimento II, níveis mais elevados de $\mathrm{Na}$ e $\mathrm{K}$ foram usados, com 4 tratamentos e 5 repetições de 10 aves cada. Em ambos os experimentos, os balanços eletrolíticos foram de 40; 140; 240 e 340 $\mathrm{mEq} / \mathrm{kg}$ de ração. 0 balanço eletrolítico causou um efeito quadrático no ganho de peso e na conversão alimentar e um aumento linear no consumo de alimento quando o balanço eletrolítico foi aumentado pela suplementação de $\mathrm{Na}$, indicando que esse íon estimula o consumo de alimento das aves nesse período. Porém, o consumo de alimento foi máximo em $202 \mathrm{mEq} / \mathrm{kg}$, quando os níveis de $\mathrm{K}$ e $\mathrm{Na}$ foram simultaneamente aumentados na dieta, indicando que o limite superior de consumo de alimento é deprimido em função do $\mathrm{K}$ em excesso. $\mathrm{O}$ balanço eletrolítico ideal foi entre 246 e $277 \mathrm{mEq} / \mathrm{kg}$ obtidos pela manipulação dos níveis de $\mathrm{Na}$ e $\mathrm{Cl}$. 


\section{INTRODUCTION}

Nutritional programs using pre-starter diets have been extensively discussed in the last decade. The adoption of this practice is justified as the bird has distinctive nutritional needs at this stage. On the other hand, it is hard to find information in literature on the electrolytic balance of broilers up to 7 days of age. The essential electrolytes for the maintenance of the osmotic pressure and acid-base balance are sodium $\left(\mathrm{Na}^{+}\right)$, potassium $\left(\mathrm{K}^{+}\right)$and chlorine $\left(\mathrm{Cl}^{-}\right)$. Besides their need in minimum amounts in the feed to satisfy the nutritional requirements, it is important to maintain the proper balance among them. The availability of theses ions may be influenced by the intestinal and kidney homeostasis regulation, as a result of increased absorption or excretion. M ongin \& Sauveur (1977) concluded that the electrolytic balance of the diet can be summarized by the equation $\mathrm{Na}^{+}+\mathrm{K}^{+}-\mathrm{Cl}^{\text {, }}$, which value expresses the amount and the ratio among these ions. These authors proposed the ideal value of $250 \mathrm{mEq} / \mathrm{kg}$ or $25 \mathrm{mEq} / 100 \mathrm{~g}$ in broiler diets. Maiorka et al. (1998) found a value of $160 \mathrm{mEq} / \mathrm{kg}$; however, Borges et al. (1999) suggested the balance of $251 \mathrm{mEq} / \mathrm{kg}$ in pre-starter diets, Rondón et al. (2000), evaluating the performance of broiler up to 7 days of age, found values which varied between 250 and $319 \mathrm{mEq} / \mathrm{kg}$ for weight gain and feed:gain ratio, respectively. The experiments of the present study aimed to determine the best electrolytic ratio $(\mathrm{Na}+\mathrm{K}-\mathrm{Cl})$ in pre-starter diets for chicks up to seven days of age.

\section{MATERIALS AND METHODS}

Seven hundred and twelve male day-old chicks was used in two experiments. The birds received diets based on corn and soybean meal ad libitum with 21.5 $\%$ protein and 2,900 kcal EM/ $/ \mathrm{kg}$, and the levels of the other nutrients were added according to the National Research Council - NRC (1994). Feedstuffs samples were taken to be analyzed for $\mathrm{Na}, \mathrm{K}$ and $\mathrm{Cl}$ content. Water samples were also analyzed for the same minerals. Sodium and potassium were determined by flame spectrophotometer (AOAC, 1990) and chlorine by $\mathrm{AgNO}_{3}$ titration (Lacroix et al., 1970) and Labtest ${ }^{\mathrm{TM}}$ kit in the water. In Experiment I, the birds (Cobb strain) were distributed in boxes with 16 birds per experimental unit in a completely random experimental design of four treatments $(40,140,240$ and $340 \mathrm{mEq} / \mathrm{kg}$ of feed) and eight replicates. The $\mathrm{K}$ level remained constant (Table 1 ), whereas $\mathrm{Na}$ and $\mathrm{Cl}$ levels were altered to obtain the desired electrolytic balance. In Experiment II, the birds (Ross strain) were distributed in batteries with 10 birds per experimental unit in a completely random experimental design with four treatments $(40,140,240$ and $340 \mathrm{mEq} / \mathrm{kg}$ of feed) and five replicates. $\mathrm{Na}$ and $\mathrm{K}$ were added at increasing levels (Table 1), and the calculated electrolytic balance "Mongin Number" were obtained by the addition of de $\mathrm{NaCl}, \mathrm{NaHCO}_{3}, \mathrm{KHCO}_{3}$ and $\mathrm{NH}_{4} \mathrm{Cl}$ in the feed. Maximum and minimum temperatures, and relative humidity w ere monitored daily. Water temperature and $\mathrm{pH}$ were recorded twice a day, at the lowest and highest temperature hours. Weight gain (WG), feed intake $(\mathrm{Fl})$ and feed:gain ratio ( $\mathrm{F}: \mathrm{G})$ were evaluated. The results were submitted to analysis of regression and, when necessary, the means were compared by the test of Tukey.

\section{RESULTS AND DISCUSSION}

From 1 to 7 days of age, a quadratic effect $(p<0,05)$ was observed for weight gain and feed:gain ratio, and to feed intake and weight gain in Experiments I and II, respectively (Figures 1 and 2 ), and the results were dependent on the electrolytes used to alter the electrolytic balance. The ideal $\mathrm{Na}+\mathrm{K}-\mathrm{Cl}$ ratio for weight gain and feed:gain was between 277 and $246 \mathrm{mEq} / \mathrm{kg}$, when $\mathrm{K}$ was fixed. When $\mathrm{K}$ and $\mathrm{Na}$ were increased, the ratio was $227 \mathrm{mEq}$ for weight gain.

The comparison of means of the treatments (Table 2) allows us to infer that special attention must be paid to high $\mathrm{Cl}$ levels in the feed $(0.77 \%)$, as well to low electrolytic balance $(40 \mathrm{mEq})$, which should not be recommended to birds at this stage. This is explained by the fact that excessive amounts of $\mathrm{Cl}$ and low or negative electrolytic balance in the feed may reduce the $\mathrm{pH}$, promoting metabolic acidosis (Johnson \& Karunajeewa, 1985; Ruiz-Lopez \& Austic, 1993), showing the direct or indirect negative effect of the excess of $\mathrm{Cl}$.

The broiler response to electrolytic balance was more evident when $\mathrm{Na}$ levels between $0.30 \%$ and $0.40 \%$ were used. Feed intake was maximum for $202 \mathrm{mEq} / \mathrm{kg}$, when $\mathrm{K}$ and $\mathrm{Na}$ levels were concurrently increased in the diet. How ever, the response was linear $(Y=173.9675$ - 0.0380X, $R^{2}=0.91$ ) when the electrolytic balance was increased by the single supplementation of $\mathrm{Na}$, indicating that this ion stimulates feed intake of birds at this stage, and that there is a limit over which feed intake is depressed as a function of excessive $K$. This reduces 
weight gain, corroborating the results of Johnson \& Karunajeewa (1985) and Borges et al. (1999). It is possible that $\mathrm{K}$ levels $(0.95$ e $1.05 \%)$ may have exceeded the birds tolerance, as the estimated requirement of this ion is $0.30 \%$ (NRC, 1994). The results obtained with increasing Na supplementation, specially the linear response in feed intake, suggest that $\mathrm{Na}$ requirements are underestimated, and the performance obtained with low electrolytic balance, due to the addition of high $\mathrm{Cl}$ levels, shows that high levels of $\mathrm{Cl}$ should be avoided.

When the electrolytic balance $(\mathrm{Na}+\mathrm{K}-\mathrm{Cl})$ was higher or low er than $240 \mathrm{mEq}$, bird performance was impaired, corroborating the hypothesis that when acid-base balance is deviated from homeostasis to alkalosis or acidosis, metabolic pathways may be altered, and are more involved in regulation of homeostasis than in animal growth (Mongin, 1981).

The average environmental temperature and relative humidity fluctuated between $28-32^{\circ} \mathrm{C}$ and $51 \%, 23-34 \%$ and $74 \%$, and water temperature was between 19 to $29 \circ \mathrm{C}$ with $\mathrm{pH}$ of 7.15 and 21 to $25^{\circ} \mathrm{C}$ with $\mathrm{pH}$ of 7.00 , in Experiments I and II, respectively. Analysis of the tap water indicated that it contained $0.7 \mathrm{ppm} \mathrm{Na}$ and traces of $\mathrm{K}$ and $\mathrm{Cl}$. Although water intake was not evaluated, previous studies showed a linear increase in water intake as the electrolytic ratio increased in the diet (Borges et al., 1999). Diets with higher levels of electrolytes can increase blood osmolarity, specially in the presence of $\mathrm{Na}$. This is important because an increase in water intake may stimulate feed intake. Despite previous studies had shown that $\mathrm{KCl}, \mathrm{NaHCO}_{3}$ and $\mathrm{NaCl}$ significantly increase water intake (Borges, 1997; Borges et al., 1998) in growing and finishing stages, Borges et al. (1999) found that diets with high levels of $\mathrm{Cl}$ and/or $\mathrm{K}$ did not stimulate water intake during the first seven days of age.

The consequence of a higher water intake promoted by diets with high electrolytic balance is higher litter humidity. However, Maiorka et al. (1998) did not find any effect of the electrolytic balance $(100,150,200$, 250 e $300 \mathrm{mEq}$ ) on the humidity of the excreta up to 7days of age. Borges et al. (1999) showed that diets containing 0.30 and $0.45 \% \mathrm{Na}$ caused litter humidity similar to those obtained with the use of commercial diets at this age. Although not quantified, diets with an electrolytic balance between 246 and $277 \mathrm{mEq}$, with $\mathrm{Na}$ levels lower than $0.45 \%$, apparently did not affect litter humidity up to 7 days of age of the chicks.

In conclusion the data of this study suggest that, the electrolytic balance of the feed $(\mathrm{Na}+\mathrm{K}-\mathrm{Cl})$ interfere in the performance of the chicks, and the ideal electrolytic balance, obtained by $\mathrm{Na}$ and $\mathrm{Cl}$ levels manipulation, was 246 and $277 \mathrm{mEq} / \mathrm{kg}$ for feed:gain ratio and weight gain, respectively. When formulating pre-starter diets which take into account the concept of electrolytic balance, extreme levels of $\mathrm{Cl}(0.77 \%)$ and $\mathrm{K}(1.05 \%)$ must be avoided.

Table 1 - Electrolyte composition of the experimental diets (\%).

\begin{tabular}{|c|c|c|c|c|c|c|}
\hline \multirow{3}{*}{$\begin{array}{l}\text { Mongin Number } \\
\text { (mEq/kg) }\end{array}$} & \multicolumn{6}{|c|}{ Experiments } \\
\hline & \multicolumn{3}{|c|}{$\mathbf{I}$} & \multicolumn{3}{|c|}{ II } \\
\hline & $\mathrm{Na}$ & K & Cl & $\mathrm{Na}$ & $\mathbf{K}$ & Cl \\
\hline 40 & 0.15 & 0.75 & 0.77 & 0.15 & 0.75 & 0.77 \\
\hline 140 & 0.25 & 0.75 & 0.57 & 0.20 & 0.85 & 0.58 \\
\hline 240 & 0.35 & 0.75 & 0.37 & 0.25 & 0.95 & 0.40 \\
\hline 340 & 0.45 & 0.85 & 0.26 & 0.30 & 1.05 & 0.21 \\
\hline
\end{tabular}


Borges SA, Maiorka A, Laurentiz AC, Fischer da Silva AV, Santin E, Ariki J

Electrolytic Balance in Broiler Chicks During the First Week of Age

Table 2 - Performance of chicks receiving different ( $\mathrm{Na}+\mathrm{K}-\mathrm{Cl})$ electrolytic balance in the diet up to 7 days of age (Experiment I and II).

\begin{tabular}{|c|c|c|c|}
\hline \multirow[t]{2}{*}{$\mathrm{mEq} / \mathbf{k g}$} & Weight gain (g) & Feed intake (g) & Feed:gain \\
\hline & \multicolumn{2}{|c|}{ Experiment I } & \\
\hline 40 & $117 c^{2}$ & 175 & $1.508 a$ \\
\hline 140 & $124 b c$ & 178 & $1.445 \mathrm{ab}$ \\
\hline 240 & $138 a$ & 185 & $1.350 \mathrm{~b}$ \\
\hline 340 & $131 \mathrm{ab}$ & 186 & 1.418ab \\
\hline \multirow[t]{2}{*}{$\mathrm{CV}^{1}(\%)$} & 5.14 & 4.93 & 4.89 \\
\hline & \multicolumn{2}{|c|}{ Experiment II } & \\
\hline 40 & 120 & 151 & 1.262 \\
\hline 140 & 125 & 155 & 1.244 \\
\hline 240 & 128 & 161 & 1.255 \\
\hline 340 & 125 & 151 & 1.213 \\
\hline $\mathrm{CV}^{1}(\%)$ & 5.34 & 4.60 & 3.33 \\
\hline
\end{tabular}

1 - Coefficient of variation.

2 - Means with different letters in the columns are different $(p<0,05)$.

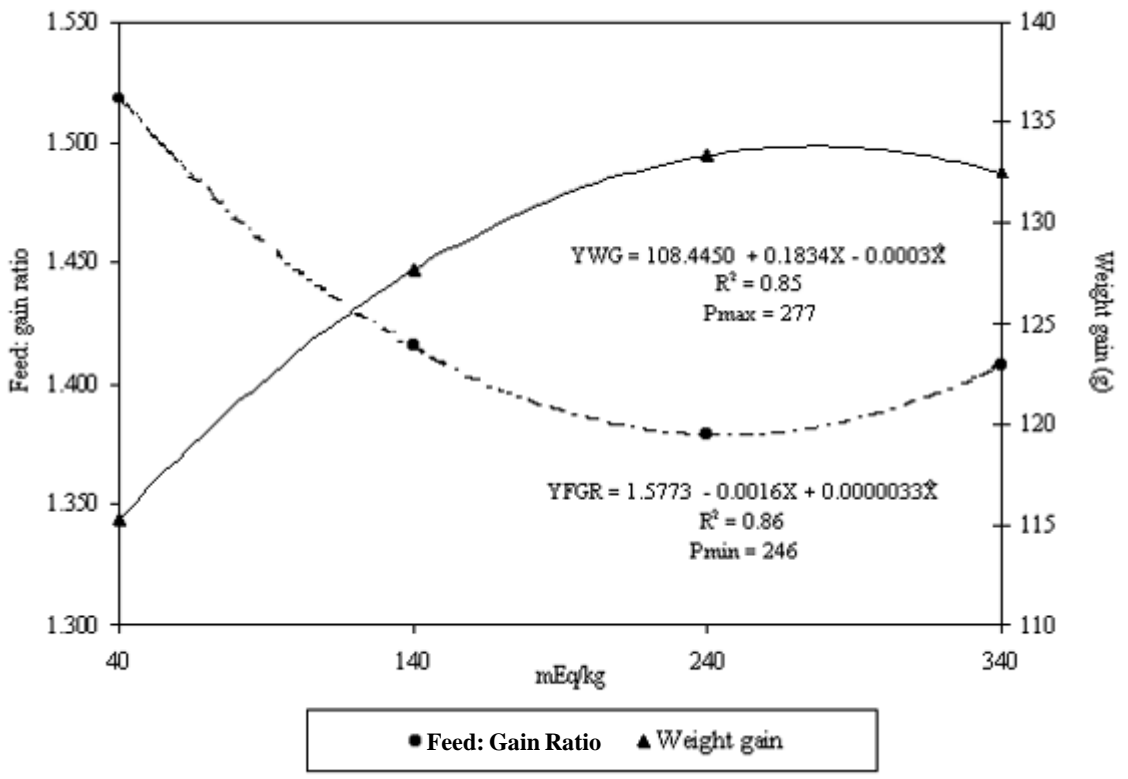

Figure 1 - Effects of the $\mathrm{Na}+\mathrm{K}-\mathrm{Cl}$ electrolytic balance of feed on weight gain and feed:gain ratio up to 7 days of age in broiler (Experiment I). 


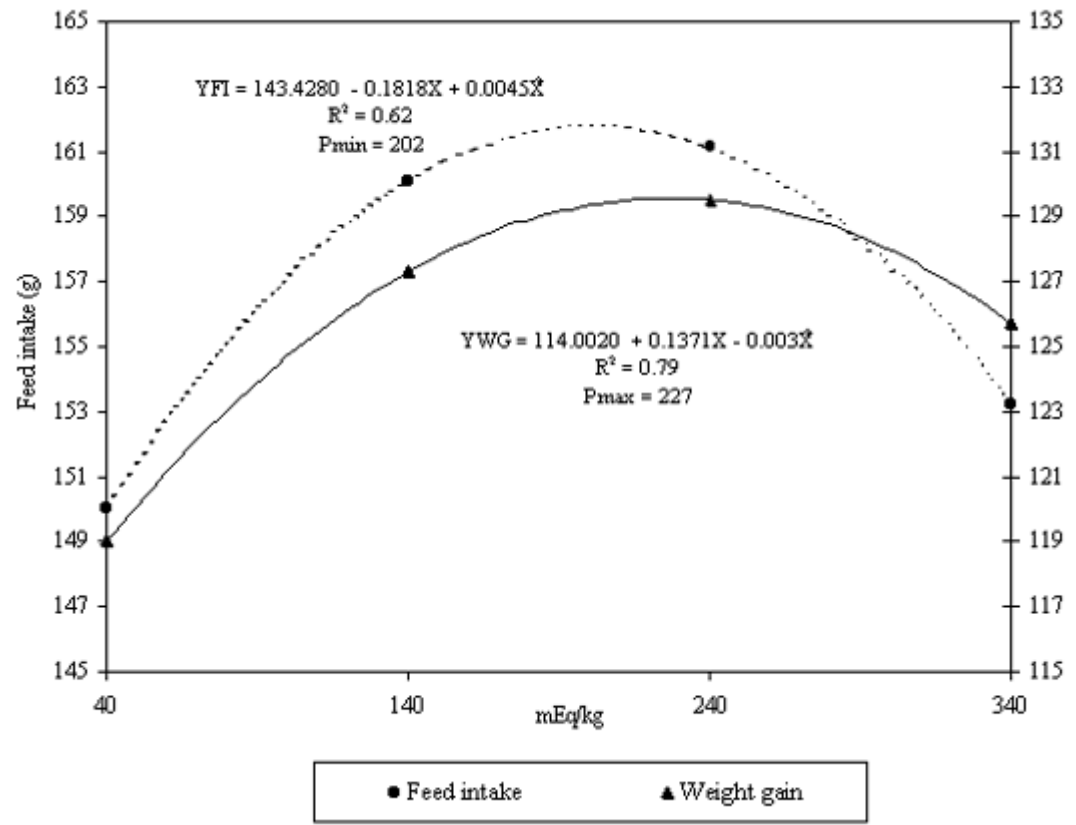

졸

Figure 2 - Effects of the $\mathrm{Na}+\mathrm{K}-\mathrm{Cl}$ electrolytic balance of feed on w eight gain and feed intake up to 7 days of age in broiler (Experiment II).

\section{REFERENCES}

Association of Official Analytical Chemists. Official Methods of Analysis. 15 $5^{\text {th }}$ ed. Arlington (VA): W illian Horwitz; 1990. 1018p.

Borges SA. Suplementação de cloreto de potássio e bicarbonato de sódio para frangos de corte durante o verão. [Dissertação]. Jaboticabal (SP): Universidade Estadual Paulista. 1997. 84p.

Borges SA, Ariki J, Jerônimo JR, M artins CL, M oraes VM B. Níveis de cloreto de sódio em rações para frangos de corte. Arquivo Brasileiro de Medicina Veterinária e Zootecnia 1998; 50(5): 619-624.

Borges SA, Ariki J, Santin E, Fischer da Silva AV, M aiorka A. Balanço eletrolítico em dieta pré-inicial de frangos de corte durante 0 verão. Revista Brasileira de Ciência Avícola 1999; 1: 175-179.

Johnson RJ, Karunajeewa $\mathrm{H}$. The effects of dietary minerals and electrolytes on the growth and physiology of the young chick. Journal of Nutrition 1985; 115: 1680-1690.

LaCroix RL, Keeney DR, Welsh LM. Potentiometric titration of chloride in plant tissue extracts using the chloride ion electrode. Communications in Soil Science and Plant Analysis 1970; 1: 1-6.

Maiorka A, Magro N, Bartels HA, Penz Jr AM. Efeito do nível de sódio e diferentes relações entre sódio potássio e cloro em dietas pré-iniciais no desempenho de frangos de corte. In: Reunião Anual da Sociedade Brasileira de Zootecnia, 1998; Botucatu. p. $478-480$.
Mongin P, Sauveur B. Interrelationships between mineral nutrition, acid-base balance, growth and cartilage abnormalities. Proceedings Poultry Science 1977; 56: 235-247.

Mongin P. Recent advances in dietary anion-cation balance: applications in poultry. Proceedings Nutrition Society 1981; 40: 285-294.

National Research Council. Nutrient Requirements of Poultry. $9^{\text {th }}$ ed. Washington (DC): National Academy Press; 1994. 155p.

Rondón EOO, Murakami AE, Furlan AC, Garcia, J. Exigências nutricionais de sódio e cloro e estimativa do melhor balanço eletrolítico da ração para frangos de corte na fase pré-inicial (1-7 dias de idade). Revista Brasileira de Zootecnia 2000; 29(4): 1162-1166.

Ruiz-Lopez B, Austic RE. The effect of selected minerals on the acid-base balance of growing chicks. Poultry Science 1993; 72: 1054-1062. 
Borges SA, Maiorka A, Laurentiz AC, Fischer da Silva AV, Santin E, Ariki J

Electrolytic Balance in Broiler Chicks During the First Week of Age 